\title{
Perintah Khidmat Masyarakat Menurut Kerangka Syariah
}

\author{
Community Service Order by Shariah Framework
}

\author{
ARIFAH RAHIMAH ISMAIL* \& MOHD. AL ADIB SAMURI ${ }^{1}$
}

\begin{abstract}
Western scholars consider community service order as the best alternative to rehabilitate offenders. However, Muslim jurists never debated the concept of community service order as a form of punishment in the Islamic judicial system. Accordingly, this article seeks to analyze the concept of community service order in the context of Islamic law by making a comparison between the concept of community service order as debated by Western scholars with the concept of ta'zir punishment by their Muslim counterpart. This aspect is analysed as an alternative concept of punishment, the discretionary power of judges, theory, or concept of the fundamental goals of punishment and penance. The research discovers that there are many similarities between the concept of community service order with the concept of punishment in Islamic ta zir. This research is significant as it potrays that the implementation of community service order practised today is a sentence that is consistent with Islamic law.
\end{abstract}

Keywords: alternative sentence, community service order, Islamic law, ta`zir punishment

Perintah khidmat masyarakat merupakan satu bentuk hukuman daripada mahkamah yang menghendaki pesalah untuk melakukan kerja-kerja kebajikan tanpa sebarang bayaran kepada pihak komuniti dalam tempoh waktu yang telah ditetapkan. Pelaksanaan perintah ini telah bermula sejak kurun ke-19M lagi, dan kini ia telah dilaksanakan oleh kebanyakan mahkamah sivil seluruh dunia kerana telah terbukti sebagai satu bentuk hukuman alternatif terbaik dalam memulihkan pesalah-pesalah jenayah. Walau bagaimanapun, pelaksanaan perintah khidmat masyarakat masih belum diperbahaskan oleh sarjana fiqah sebagai satu bentuk hukuman dalam sistem peradilan Islam. Ia menimbulkan persoalan adakah perintah khidmat masyarakat adalah selaras dengan prinsip penghukuman syariah dalam konteks hukuman takzir? Perintah khidmat masyarakat tidak seperti hukuman hudud dan qisas yang ditentukan oleh syarak melalui alQuran dan al-Sunah. Oleh demikian, pelaksanaan perintah tersebut mungkin boleh dinilai dalam konteks hukuman takzir. Sehubungan itu, kajian ini meneliti sejauh mana pelaksanaan perintah khidmat masyarakat boleh diterima dalam kerangka perundangan fiqah Islam. Justeru, penilaian dilihat dengan membuat perbandingan antara konsep perintah khidmat masyarakat dengan konsep takzir terhadap beberapa aspek perbahasan seperti pelaksanaan hukuman alternatif, kuasa budi bicara hakim, teori asas penghukuman serta konsep penebusan dosa. Setiap aspek tersebut akan dianalisis untuk melihat hubungan antara perintah khidmat masyarakat dengan perundangan Islam.

\footnotetext{
${ }^{1}$ Arifah Rahimah Ismail*(Corresponding author), Master Student, Dept. of Syariah, Faculty of Islamic Studies, Universiti Kebangsaan Malaysia, 43600 BANGI, Selangor, Malaysia, email: arifah@siswa.ukm.edu.my; Mohd. Al Adib Samuri, Ph.D., Senior Lecturer, Dept. of Syariah, Faculty of Islamic Studies, Universiti Kebangsaan Malaysia, 43600 BANGI, Selangor, Malaysia, email: al_adib@ukm.edu.my.
} 


\section{Konsep Hukuman Alternatif}

Hukuman alternatif dapat difahami sebagai salah satu bentuk hukuman gantian atau hukuman pilihan selain daripada hukuman asal. Konsep hukuman alternatif ini juga dapat ditakrifkan sebagai perihal hakim yang menjatuhkan hukuman selain daripada hukuman yang diperuntukkan terhadap pesalah terbabit di bawah seksyen ia didapati bersalah (Siti Zubaidah 2011). Menurut Siti Zubaidah (2011) lagi, hukuman alternatif dalam konteks semasa sering dikaitkan dengan perintah khidmat masyarakat. Pelaksanaan hukuman alternatif boleh dilihat menerusi pandangan sarjana Barat dan Islam. Pelaksanaan hukuman alternatif di negara-negara Barat mula muncul sekitar akhir tahun 1990-an apabila penjara-penjara di sekitar Amerika Syarikat mengalami kepadatan yang sangat membimbangkan (Baer 1991). Ia telah menyebabkan badan keadilan jenayah mula merangka hukuman alternatif lain yang boleh menyelesaikan masalah tersebut, dan mereka mendapati hukuman perantaraan yang berasaskan komuniti mampu menjadi hukuman alternatif terbaik setakat ini. Antara bentuk hukuman perantaraan yang boleh dijadikan sebagai hukuman alternatif tersebut adalah seperti perintah khidmat masyarakat, penyeliaan intensif, pemantauan elektronik dan tahanan dalam rumah (home confinement). Carter et al. (1987) mendakwa, perintah khidmat masyarakat merupakan salah satu bentuk hukuman alternatif kepada hukuman pemenjaraan, denda, penebusan atau lain-lain hukuman tradisional. Hukuman alternatif dilaksanakan kerana hukuman pemenjaraan dilihat terlalu keras kepada pesalah dan hukuman denda dilihat terlalu membebankan pesalah-pesalah miskin (Hudson \& Galaway 1990). Justeru, konsep hukuman alternatif adalah satu keadaan bagi hakim membuat pilihan dalam menjatuhkan hukuman selain daripada hukuman asal yang telah diperuntukkan bagi kesalahan terbabit atas alasan-alasan yang difikirkan munasabah oleh hakim.

Sementara itu, dalam perundangan fiqah Islam, konsep hukuman alternatif dapat dilihat dalam konteks `uqubah badliyyah iaitu satu hukuman yang menggantikan hukuman asal yang tidak dapat dilaksanakan di atas sebab-sebab syarie seperti pelaksanaan hukuman diat yang menggantikan hukuman qisas, atau pelaksanaan hukuman takzir yang menggantikan hukuman hudud dan qisas. Ia dapat dilihat dalam beberapa keadaan, hukuman takzir boleh dijadikan sebagai hukuman alternatif kepada hukuman hudud atau qisas yang tidak dapat dilaksanakan kerana tidak cukup syarat-syarat pelaksanaan atau gugur salah satu daripada syarat-syarat tersebut (Audah 1993). Sebagai contoh, dalam kes zina yang wujud keraguan atau dalam kes mencuri oleh pesalah yang kudung tangannya, hukuman takzir penjara boleh dijadikan hukuman alternatif kepada hukuman rejam dan sebatan, atau hukuman potong tangan. Maknanya, pesalah jenayah yang telah disabitkan kesalahan tetap akan dikenakan hukuman lain sebagai gantian akibat elemen-elemen asas pelaksanaan hukuman asal tidak dapat dipenuhi. Ini secara tidak langsung, menjelaskan bahawa hukuman takzir boleh dianggap sebagai satu bentuk hukuman alternatif dalam perundangan Islam. Namun begitu, sejauh manakah hukuman perintah khidmat masyarakat yang dibincangkan oleh sarjana Barat menepati konsep alternatif dalam perundangan Islam?

Berdasarkan perbincangan di atas, secara dasarnya, dapat disimpulkan bahawa konsep hukuman alternatif wujud dalam perundangan sivil dan Islam. Hukuman alternatif dalam perundangan sivil melibatkan beberapa bentuk hukuman seperti perintah khidmat masyarakat, penyeliaan intensif, pemantauan elektronik dan home confinement. Berbeza dengan perundangan Islam, hukuman alternatif hanya melibatkan hukuman diat dan takzir. Namun, perlu difahami bahawa konsep hukuman takzir merupakan satu konsep yang terlalu luas dan meliputi pelbagai bentuk hukuman dari seberat-berat hukuman (iaitu hukuman mati) sehinggalah kepada seringan-ringan hukuman (seperti nasihat atau amaran). Maka, tidak mustahil juga perintah khidmat masyarakat boleh dimasukkan sebagai salah satu daripada bentuk hukuman takzir. Jika di dalam perundangan sivil, hukuman alternatif bertindak sebagai gantian kepada hukuman pemenjaraan ekoran masalah kepadatan penjara yang dialami oleh 
kebanyakan penjara pada hari ini di samping masalah hukuman terlalu keras dan tidak setimpal dengan keadaan pesalah terutamanya pesalah kanak-kanak atau mereka yang terbabit dengan kesalahan yang lebih ringan. Berbeza dengan pelaksanaan hukuman alternatif di dalam Islam khususnya hukuman takzir, ia bertindak sebagai hukuman ganti apabila hukuman hudud atau qisas tidak dapat dilaksanakan ekoran tidak cukup syarat-syarat pelaksanaannya atau gugur salah satu daripada syarat-syarat tersebut. Ini menunjukkan bahawa dasar kepada pelaksanaan hukuman alternatif bagi kedua-dua bentuk perundangan ini adalah berbeza.

Walaupun begitu, jika ditinjau kembali pelaksanaan perintah khidmat masyarakat yang dilaksanakan di mahkamah sivil pada hari ini, kebanyakan hukumannya dikenakan terhadap pesalah-pesalah muda, pesalah atas kesalahan kali pertama atau pesalah yang disabitkan dengan kesalahan-kesalahan kecil. Di antara bentuk kesalahan kecil tersebut adalah seperti kesalahan lalu lintas, kerosakan harta benda dan kesalahan mencuri dalam nilaian yang kecil. Hal ini juga berlaku dalam pelaksanaan hukuman takzir. Ia dapat dilihat daripada sebuah hadis yang diriwayatkan oleh al-Nasa'i (2012), Kitab Qat'i al-Sariq pada bahagian Bab al-Thamar Yusraq ba'd 'an Yu'wiyah al-Jariyn. Kefahaman daripada hadis tersebut adalah tentang ketika Rasulullah s.a.w. ditanya mengenai buah yang dicuri ketika masih di pohon, Baginda menjawab bahawa apabila seseorang itu mencuri buah kerana terpaksa, maka tidak akan dikenakan denda selagi dia tidak membawanya pulang. Namun, jika dia membawanya pulang, maka akan dikenakan denda dengan membayar dua kali ganda daripada nilai barang yang dicurinya dan diberikan hukuman sebagai peringatan. Jika seseorang itu mencuri buah-buahan yang berada di tempat penyimpanan yang nilainya adalah mencapai harga sebuah perisai, maka tangannya harus dipotong. Meskipun begitu, jika dia mencurinya tetapi kurang daripada nilai tersebut, maka akan dikenakan denda dengan membayar dua kali ganda nilaian tersebut dan harus diberi hukuman sebagai peringatan.

Kefahaman hadis di atas menerangkan bentuk hukuman kepada mereka yang melakukan kesalahan mencuri tetapi tidak cukup syaratnya untuk dilaksanakan hukuman hudud iaitu hukuman potong tangan. Pada hadis dimaksudkan, terdapat dua keadaan yang telah menghalang pelaksanaan hukuman potong tangan iaitu mereka yang telah melakukan jenayah dalam keadaan terpaksa, dan kesalahan mencuri yang tidak mencapai hisab untuk dibolehkan pelaksanaan hukuman hudud. Walau bagaimanapun, Nabi s.a.w. tetap menjatuhkan hukuman ke atas mereka iaitu dengan membayar dua kali ganda nilaian barang yang dicuri tersebut. Maka, fuqaha mentafsirkan nilaian 'dua kali ganda' itu sebagai satu hukuman takzir atas tujuan sebagai peringatan kepada pesalah (al-Suyuti \& al-Sindi 1999). Oleh yang demikian, dapat dikatakan bahawa pelaksanaan hukuman takzir juga dilaksanakan terhadap mereka yang melakukan kesalahan-kesalahan kecil seperti mana kesalahan mencuri dalam nilaian yang kecil. Keadaan ini hampir serupa dengan pelaksanaan perintah khidmat masyarakat seperti yang telah dibahaskan oleh para sarjana Barat.

Di samping itu, hukuman perintah khidmat masyarakat juga dilihat sebagai satu hukuman alternatif tambahan atau alternatif bersyarat kepada hukuman perintah pengawasan dan hukuman pelepasan bersyarat. Maknanya, hukuman perintah khidmat masyarakat perlu digabungkan dengan suatu bentuk hukuman yang lain (Brennan \& Mason 1983). Hal ini turut berlaku dalam pelaksanaan hukuman takzir. Hukuman takzir juga boleh dilihat sebagai hukuman tambahan kepada hukuman asal dalam kes hudud dan qisas ('Audah 1993). Sebagai contoh, hukuman buang daerah kepada pesalah zina yang belum berkahwin sebagai tambahan kepada hukuman sebatan hudud. Ia adalah menurut pandangan Abu Hanifah. Selain itu, hukuman 40 sebatan hadd terhadap pesalah yang minum minuman memabukkan ditambah menjadi 80 sebatan, dilihat sebagai satu hukuman takzir. Ia adalah menurut pandangan golongan mazhab Syafie. Berdasarkan perbahasan, jelas menunjukkan bahawa konsep pelaksanaan hukuman alternatif menurut pandangan sarjana Barat dan Islam mempunyai kewujudan persamaan dari sudut dasar pelaksanaannya. Justeru, ini membuktikan bahawa 
pelaksanaan perintah khidmat masyarakat adalah satu hukuman alternatif, dan didapati selari dengan apa yang terdapat dalam perundangan Islam.

\section{Kuasa Budi Bicara Hakim}

Secara asasnya, hakim mempunyai panduan dalam menetapkan sesuatu hukuman kepada pesalah jenayah melalui peruntukan-peruntukan perundangan yang disediakan oleh badan perundangan kepada hakim. Walau bagaimanapun, terdapat beberapa ruang di dalam peruntukan tersebut yang membolehkan hakim membuat sesuatu keputusan berdasarkan budi bicaranya (Siti Zubaidah 2011). Bagi beberapa keadaan, kuasa budi bicara hakim boleh diterima pakai dalam memutuskan sesuatu kes jenayah. Namun begitu, sejauh manakah kuasa yang dimiliki oleh hakim dalam menentukan sesuatu hukuman dan sejauh manakah hakim tersebut bebas menggunakan budi bicaranya, menjadi satu persoalan yang perlu dirungkaikan dengan melihat perbandingan di antara perintah khidmat masyarakat dan hukuman takzir.

Pelaksanaan perintah khidmat masyarakat di negara-negara Barat dilihat sebagai satu hukuman yang ditentukan melalui budi bicara sistem keadilan jenayah (discretionary punishment) (Panzer 1997). Ini ada dijelaskan oleh Rubin (1985-1986) bahawa hakim mahkamah kanak-kanak secara tradisinya diberi kuasa sepenuhnya (discretionary power) untuk menentukan hukuman kepada pesalah kanak-kanak. Ia secara tidak langsung bermaksud, pelaksanaan hukuman perintah khidmat masyarakat adalah tertakluk kepada kebijaksanaan hakim dalam menentukan hukuman tersebut terhadap pesalah termasuklah pesalah kanakkanak. Kuasa budi bicara hakim yang dimaksudkan adalah kebijaksanaan hakim dalam memutuskan sebarang bentuk keputusan yang berkaitan dengan pelaksanaan perintah khidmat masyarakat. Ini memandangkan perintah khidmat masyarakat tidak mempunyai statut perundangan yang khusus dalam pelaksanaannya, sehingga memaksa hakim untuk membuat keputusan yang bijak dalam memutuskan keputusan berkaitan umur pesalah yang layak menjalani hukuman, bentuk kesalahan pesalah, tempoh pelunasan hukuman dan sebagainya.

Walaupun begitu, ia tidak bermakna hakim boleh memutuskan keputusan pelaksanaan hukuman tersebut dengan sewenang-wenangnya. Pelaksanaan hukuman tersebut tertakluk kepada kelulusan pihak pemerintah negara masing-masing. Pelaksanaan perintah bagi setiap negara adalah berbeza-beza (Hudson \& Galaway 1990). Sebagai contoh, dalam aspek penetapan umur pesalah yang layak menjalani perintah, ia agak berbeza di antara satu negara dengan negara yang lain. Jika di England dan Kanada, pemilihan pesalah adalah di kalangan pesalah muda yang berumur 21 ke bawah (Vass \& Menzies 1989), berbeza dengan Afrika Selatan yang memilih pesalah berumur 15 tahun ke atas (Skeen 1988). Manakala di Amerika Syarikat dan New Zealand tidak menetapkan had umur bagi pesalah dan hanya menetapkan bentuk kesalahan sahaja (Leibrich et al. 1986). Ini membuktikan secara umumnya, pelaksanaan perintah khidmat masyarakat bukan hanya sesuai kepada pesalah kanak-kanak sahaja, malah ia juga boleh dikenakan terhadap pesalah-pesalah dewasa bergantung pada keperluan yang telah diluluskan oleh pihak pemerintahan negara masing-masing.

Sementara itu, dalam perundangan Islam, Abu Zahrah (1974) berpandangan bahawa takzir dapat dilihat sebagai satu pembalasan atau hukuman yang tidak ditetapkan nas syarak dalam menentukan kadar hukumannya, maka ia diserahkan kepada hakim berdasarkan ijtihad mereka. Ini bermakna hakim atau pemerintah mempunyai kuasa sepenuhnya dalam menetapkan sebarang bentuk hukuman yang bersesuaian terhadap pesalah, dengan melihat kepada keadaan diri pesalah dan kadar kesalahan yang telah dilakukan (Ibn `Abidin 1966). Walaupun begitu, timbul persoalan sejauh manakah kuasa yang dimiliki oleh hakim tersebut dalam memutuskan hukuman, adakah ia bersifat mutlak atau terbatas?

Oleh yang demikian, para fuqaha telah membahaskan persoalan ini dengan panjang lebar di dalam kitab-kitab fiqah. Perbahasan mereka merangkumi aspek penentuan jenis kesalahan, bentuk-bentuk hukuman takzir terhadap pesalah jenayah, kadar hukuman dan 
bentuk pelaksanaan hukuman tersebut. Secara asas, perbezaan pandangan di kalangan fuqaha tidak berlaku dalam perbahasan berkaitan jenis kesalahan dan bentuk-bentuk hukuman takzir. Namun, perbezaan tersebut telah wujud pada kadar hukuman yang dilaksanakan. Sebagai contoh, penentuan ulama fiqah dalam bentuk-bentuk hukuman takzir seperti hukuman mati, sebatan, pemenjaraan, buang negeri dan sebagainya tidak menjadi permasalahan yang besar untuk dibahaskan kerana hampir kesemuanya bersepakat dengan bentuk-bentuk hukuman tersebut. Namun perbezaan pandangan kalangan mereka dalam membahaskan kadar hukuman takzir telah menimbulkan persoalan untuk melihat sejauh manakah kuasa budi bicara hakim dalam memutuskan hukuman takzir ini sama ada ia boleh melebihi had hudud atau sebaliknya.

Dalam membahaskan persoalan ini, hampir kebanyakan ulama fiqah daripada golongan Hanafiyyah, Syafi iyyah dan Hanabilah berpandangan bahawa kadar maksimum bagi hukuman takzir adalah tidak boleh melebihi kadar had minimum dalam hukuman hudud. Sebagai contoh, dalam isu berkaitan had maksimum bagi sebatan takzir, ulama golongan Hanafiyyah berpandangan bahawa had maksimum bagi sebatan takzir adalah 79 sebatan, sementara menurut Abu Yusuf adalah 75 sebatan (al-Kasani 1996). Ini adalah kerana menurut pandangan mereka, had sebatan maksimum bagi sebatan hudud adalah 80 sebatan bagi kesalahan tuduhan qazaf dan minum arak, maka hukuman sebatan takzir hendaklah dikurangkan daripada jumlah tersebut. Manakala menurut pandangan daripada golongan Syafi iyyah, had maksimum sebatan takzir bagi golongan hamba adalah 19 sebatan, dan bagi golongan merdeka adalah 39 sebatan (al-Syirazi 1995). Sebabnya, mengambil kira had maksimum sebatan hudud bagi golongan hamba adalah 20 sebatan, dan golongan merdeka adalah 40 sebatan atas kesalahan minum arak. Pada pandangan golongan Hanabilah, sebahagian daripada mereka menerima pandangan golongan Hanafiyyah manakala sebahagian lagi menerima pandangan golongan Syafi iyyah (Ibn Qudamah 1996). Namun begitu, pendapat yang agak ketara telah dikeluarkan oleh ulama golongan Malikiyyah yang berpandangan bahawa hakim diberi kuasa sepenuhnya dalam menentukan hukuman kepada pesalah-pesalah takzir (Ibn Farhun 1995). Ini bermakna, had hukuman sebatan tersebut adalah boleh secara sama, kurang, atau lebih daripada had hukuman hudud.

Oleh yang demikian, berdasarkan kepada perbahasan tersebut, dapat disimpulkan bahawa kuasa budi bicara yang dimiliki oleh hakim dalam menentukan hukuman takzir adalah tidak bersifat mutlak sepenuhnya dan masih tertakluk kepada had yang telah ditetapkan oleh para ulama fiqah seperti Hanafi, Syafie dan Hanbali. Walaupun Maliki dilihat cuba memberi kuasa yang mutlak sepenuhnya kepada hakim dalam menentukan hukuman takzir, namun ia masih perlu mengikut garis panduan yang ditetapkan oleh kerajaan yang memerintah atas dasar siyasah syar iyyah. Siyasah ini sah apabila sesuatu hukuman yang dilaksanakan tersebut tidak bertentangan dengan apa yang terkandung dalam al-Quran dan al-Sunah (El-Ewa 1999).

Berdasarkan kepada hujah-hujah yang dikemukakan di atas, didapati konsep dasar kuasa budi bicara hakim dalam memutuskan perintah khidmat masyarakat menurut perundangan sivil adalah hampir sama dengan konsep hukuman takzir dalam perundangan Islam. Ia dapat dilihat melalui kuasa yang dimiliki oleh hakim dalam menentukan bentuk kesalahan, hukuman dan kadar hukuman yang boleh dikenakan kepada pesalah. Kesemua aspek tersebut diletakkan sepenuhnya di bawah kuasa hakim untuk menentukannya sama ada dalam konteks pelaksanaan perintah khidmat masyarakat mahupun dalam konteks hukuman takzir. Walaupun begitu, kuasa yang dimiliki oleh hakim dalam melaksanakan perintah khidmat masyarakat ini masih tertakluk kepada kelulusan daripada badan pemerintah negara masingmasing supaya matlamat pelaksanaan hukuman tersebut boleh tercapai. Hal ini turut berlaku dalam konteks perundangan takzir, para hakim perlu mengikut garis panduan yang telah ditetapkan oleh badan pemerintah negara atas dasar siyasah syar iyyah. Dasar siyasah syar'iyyah inilah yang membezakan di antara hukuman yang diasaskan oleh Barat dan hukuman dalam Islam yang diasaskan oleh Allah s.w.t. seperti yang termaktub dalam al-Quran dan al-Sunah. 
Justeru, dapatlah disimpulkan bahawa konsep budi bicara hakim dalam pelaksanaan perintah khidmat masyarakat menyerupai apa yang terdapat dalam konteks hukuman takzir.

\section{Teori Asas Penghukuman}

Dalam sistem keadilan jenayah moden, terdapat beberapa teori asas yang telah dibicarakan oleh para sarjana Barat bagi setiap hukuman yang dilaksanakan. Setiap teori yang diangkat bagi setiap hukuman tertentu mempunyai falsafah dan matlamat penghukuman yang tersendiri. Perintah khidmat masyarakat juga tidak sunyi daripada menerima beberapa teori asas dan falsafah yang tersendiri biarpun setiap teori tersebut saling berkonflik di antara satu sama lain. Manakala dalam sistem perundangan Islam, teori atau matlamat asas penghukuman takzir ini telah dibincangkan dalam konteks falsafah perundangan Islam. Ini kerana setiap hukum yang diputuskan dalam perundangan Islam sama ada dari sudut ibadat, muamalat, jenayah dan seterusnya mempunyai matlamat, falsafah serta hikmah di sebalik pensyariatannya.

Antara teori yang sering mendapat tempat di kalangan para sarjana Barat adalah teori pemulihan dan teori pembaikpulihan. Teori pemulihan (rehabilitative) menekankan rawatan kepada individu yang bersalah dengan memujuknya supaya melakukan perubahan pada tingkah laku mereka daripada mengulangi jenayah tersebut pada masa akan datang melalui hubungan sosial bersama masyarakat (Walgrave \& Geudens 1996). Ia bertujuan memberi ruang kepada pesalah untuk membetulkan kesalahan mereka dan ini secara tidak langsung dapat mengelakkan pesalah daripada terjebak dengan kesan negatif akibat hukuman pemenjaraan (Umbreit 1981). Di samping itu, teori yang hampir sama dengan teori pemulihan iaitu teori pembaikpulihan (restorative) juga sering dibahaskan oleh para sarjana. Mereka berpandangan, fungsi keadilan dalam jenayah adalah bukan untuk menghukum dan bukan juga untuk mendidik, malahan adalah untuk membaiki atau membayar ganti rugi bagi kemudaratan yang disebabkan oleh pesalah. Matlamat utama teori ini adalah untuk memulihkan kecederaan yang dilakukan pesalah terhadap mangsa dan masyarakat, dengan menyedari bahawa setiap pihak saling berkepentingan di antara satu sama lain (Flacks 2006). Teori ini dilihat hampir

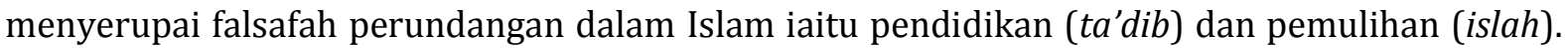
Ia telah dijelaskan oleh Ibn 'Asyur (1978) bahawa tujuan pensyariatan undang-undang jenayah Islam adalah untuk memberi pendidikan ( $\left.t a^{\prime} d i b\right)$ kepada pesalah dan masyarakat keseluruhannya. Hal sedemikian dapat dilihat, apabila sesuatu hukuman itu dilaksanakan ke atas pesalah, ia turut memberi kesan atau pengajaran (zajr) kepada masyarakat awam supaya tidak lagi melakukan kesalahan seperti itu.

Selanjutnya, teori yang dilihat mendasari perintah khidmat masyarakat adalah teori pencegahan (deterrence) yang menghendaki satu hukuman yang sesuai untuk mencegah pesalah daripada melakukan kesalahan di samping mencegah berlakunya pengulangan jenayah di kalangan pesalah itu sendiri atau di kalangan masyarakat awam (Perrier \& Pink 1985). Matlamat pelaksanaan undang-undang jenayah Islam juga adalah untuk mencegah berlakunya kemungkaran atau untuk mengurangkan pengulangan jenayah di kalangan pesalah dan masyarakat (Abu Rakhyah 2010). Ia turut dijelaskan oleh al-Mawardi (1985) bahawa hudud merupakan pencegah yang ditentukan oleh Allah s.w.t. untuk menghalang manusia daripada melakukan jenayah. Manakala hukuman takzir adalah seperti hudud dari sudut memberi pengajaran, memperbaiki dan menghalang seseorang daripada melakukan jenayah. Ini bermakna matlamat pensyariatan hukuman takzir adalah sama seperti matlamat pensyariatan hukuman hudud dan qisas. Perintah khidmat masyarakat juga dilihat menerima teori pemulihan semula (reparative) atau simbolik kepada pampasan yang menjadi dasar kepada pelaksanaannya. Ini kerana menurut Carter et al. (1987), pesalah perlu membayar semula kerosakan yang dilakukan oleh mereka dengan melaksanakan khidmat tanpa bergaji kepada komuniti yang memerlukan tenaga kerja. Teori pemulihan semula (reparative) menyerupai konsep penebusan dosa dalam undang-undang jenayah Islam yang disebut sebagai kafarah. 
Konsep penebusan dosa (taubat) bermaksud pesalah yang dikenakan hukuman di atas dunia ini akan selamat daripada hukuman di akhirat kelak (El-Ewa 1999).

Berdasarkan kepada perbahasan tersebut, didapati wujudnya persamaan antara teori asas perintah khidmat masyarakat dengan falsafah undang-undang jenayah Islam. Walaupun terdapat banyak teori asas yang telah dibahaskan oleh para sarjana dalam menilai apakah teori yang sesuai bagi mendasari pelaksanaan perintah masyarakat ini, namun kesemua teori tersebut dilihat mempunyai persamaan dengan falsafah undang-undang jenayah Islam. Di antara persamaan tersebut adalah teori pemulihan (rehabilitative) dan pembaikpulihan (restorative) dalam konteks perintah khidmat masyarakat, yang menyerupai falsafah pendidikan ( $\left.t a^{\prime} d i b\right)$ dan pemulihan (islah) dalam konteks undang-undang jenayah Islam. Manakala teori lain yang mendasari perintah khidmat masyarakat seperti pencegahan (deterrence), pembalasan (retributive) dan pemulihan semula (reparative), juga wujud dalam perbahasan falsafah undang-undang jenayah Islam.

\title{
Konsep Penebusan Dosa
}

Pelaksanaan perintah khidmat masyarakat juga merupakan satu bentuk pemulihan semula (reparative) yang efektif atau simbolik kepada pampasan (Baer 1991). Teori pemulihan semula (reparative) ini menghendaki pesalah membayar semula kerosakan yang dilakukan mereka dengan melaksanakan khidmat kepada komuniti tanpa sebarang upah (Perrier \& Pink 1985). Menurut Reddy (1991), asas pelaksanaan hukuman perintah khidmat masyarakat adalah diambil daripada prinsip 'Old Testament' yang menghendaki pesalah membuat kerja-kerja kebajikan untuk menebus kesalahan mereka. Justeru, ia juga boleh dilihat sebagai satu bentuk pengembalian (restitution) yang terdapat dalam perintah khidmat masyarakat. Sebabnya, ia menghendaki pesalah yang melakukan kesalahan, dihukum untuk melakukan khidmat kepada komuniti sebagai penebusan kepada kerosakan dan kesalahan yang dilakukannya (Groves 1977). Manakala berdasarkan prinsip Islam, konsep penebusan dosa sering dikaitkan dengan mereka yang melakukan kesalahan-kesalahan kecil, iaitu dengan melakukan amalan kebaikan. Ini adalah berdasarkan kepada firman Allah s.w.t. dalam surah Hud (11:114) yang berbunyi:

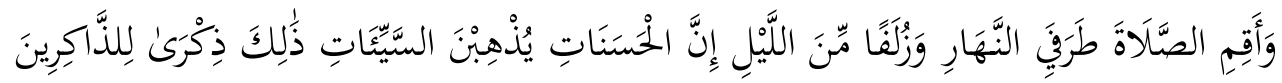

\begin{abstract}
Maksud: Dan dirikanlah solat pada dua bahagian siang (pagi dan petang) dan pada ketika waktu permulaan malam (iaitu Maghrib dan 'Isya'). Sesungguhnya amal-amal kebaikan itu menghapuskan kejahatan. Perintah-perintah Allah yang demikian itu menjadi peringatan bagi orang yang mahu beringat.
\end{abstract}

Berdasarkan ayat al-Quran di atas, secara kasarnya dapat difahami bahawa segala kejahatan yang telah dilakukan oleh manusia boleh dihapuskan dengan melakukan amal kebaikan terutamanya dengan menunaikan solat. Namun begitu, timbul persoalan adakah hanya dengan menunaikan solat sahaja, maka segala dosa akibat perbuatan jahat akan dihapuskan? Apakah maksud sebenar amal kebaikan (al-hasanat) yang dimaksudkan dalam ayat tersebut? Persoalan lain juga timbul, adakah segala kejahatan yang dilakukan manusia merangkumi dosa-dosa besar dan kecil, boleh dihapuskan dengan melalui solat? Oleh yang demikian, petikan ayat inna al-hasanat yuzhibna al-sayyi'at yang menjadi fokus perbincangan dalam topik ini telah dibahaskan oleh golongan mufasirin dengan pelbagai pandangan. Menurut al-Tabari (2005) dalam tafsirnya, perkataan al-hasanat ialah perbuatan-perbuatan baik yang membawa pengertian solat lima waktu sebagaimana difardukan oleh Allah s.w.t. Pandangan yang dibawa oleh al-Tabari ini mengambil kira daripada kebanyakan ulama tafsir seperti Ibn 'Abbas, al-Khuraizi, Ibn Jarir dan sebagainya. Pandangan ini turut disokong oleh al-Nawawi (1999) dalam membahaskan hadis yang menjadi sebab turunnya ayat (asbab al-nuzul) tersebut. 
Al-Nawawi turut mengambil pandangan daripada Mujahid yang mendakwa bahawa perkataan al-hasanat tersebut membawa maksud ucapan Subhan Allah wa al-Hamd li Allah wa la 'ilah 'illa Allah wa Allah Akbar (Maha Suci Allah, dan Segala Puji bagi Allah, dan tiada tuhan selain Allah, dan Allah Maha Besar). Tafsiran tersebut berbeza dengan tafsiran yang dibawa oleh Ibn Kathir (1997), petikan ayat inna al-hasanat yuzhibna al-sayyi'at membawa maksud 'bahawa sesungguhnya dengan melakukan kebaikan akan menghapus dosa-dosa yang telah lalu'. Ia merujuk kepada segala bentuk kebaikan yang boleh menghapus dosa-dosa yang lalu. Namun, hujah beliau yang selanjutnya hanya memfokuskan 'kebaikan' tersebut dengan amalan-amalan solat sahaja. Ini terbukti dengan hadis-hadis yang menjadi hujah beliau semuanya berkaitan dengan amalan solat.

Sementara itu, pandangan Sayyid Qutb (1987) telah menjelaskan bahawa di awal petikan ayat tersebut telah menerangkan tentang perintah mendirikan solat dengan sempurna, kemudian diiringi dengan petikan inna al-hasanat yuzhibna al-sayyi'at yang bermaksud 'perbuatan-perbuatan yang baik itu menghapuskan dosa-dosa perbuatan yang buruk'. Jelasnya lagi, nas ini merupakan nas yang umum iaitu merangkumi segala perbuatan yang baik dan beliau menekankan amalan solat kerana ia merupakan sebaik-baik amalan untuk menghapuskan perbuatan-perbuatan buruk. Melalui penjelasan Sayyid Qutb, maksud amalan baik bukanlah hanya sekadar amalan solat sahaja, bahkan juga segala amalan baik lain yang boleh dilakukan untuk menghapuskan dosa. Selanjutnya, al-Shawkani (1995) mendalami pandangan tersebut dengan menjelaskan bahawa pengertian al-hasanat itu adalah perbuatanperbuatan yang baik secara umum dan termasuk di dalamnya adalah amalan solat, manakala perkataan al-sayyi'at bermaksud dosa-dosa kecil. Ini bererti, segala perbuatan yang baik akan menghapuskan dosa-dosa kecil yang telah dilakukan oleh manusia.

Berdasarkan kepada hujah-hujah tersebut, kebanyakan ulama tafsir bersetuju menyatakan ayat inna al-hasanat yuzhibna al-sayyi'at membawa maksud segala perbuatan atau amalan yang baik boleh menghapuskan perbuatan-perbuatan buruk kecuali pandangan daripada al-Tabari dan Mujahid. Maksud amalan yang baik tersebut adalah satu nas yang berbentuk umum, dan ia tidak dikhaskan sebagai amalan solat sahaja walaupun hujah yang dibawa oleh Ibn Kathir banyak membawa hadis-hadis berkaitan solat. Manakala perbuatan buruk tersebut pula adalah satu nas yang khusus iaitu dosa-dosa kecil sahaja menurut pandangan al-Shawkani. Secara ringkas, hampir kebanyakan ulama memahaminya sebagai segala amalan yang baik serta boleh menghapuskan kesalahan yang kecil kerana maksud ayat tersebut dinilai berdasarkan kepada sebab turunnya ayat. Dalam hadis yang diriwayatkan oleh al-Bukhari (2012), Kitab al-Muharibiyn min Ahl al-Kufr wa al-Riddah sebagaimana pada Bab Idha Aqarr bi al-Hadd wa lam Yubayyin hal li al-'Imam 'an Yastur 'Alayh, apa yang boleh difahami daripada hadis tersebut adalah tentang seorang lelaki telah datang kepada Rasulullah s.a.w., sambil mengaku dirinya telah melakukan sesuatu pelanggaran, serta meminta Baginda agar melaksanakan hukuman ke atasnya. Baginda tidak bertanyakan pula tentang pelanggaran tersebut. Kemudian, setelah masuknya waktu solat, didapati lelaki tersebut turut mendirikan solat bersama Nabi s.a.w. Apabila selesai, Baginda sekali lagi dihampiri oleh lelaki tersebut serta diperdengarkan pengakuan yang sama. Lalu Baginda menjelaskan bahawa solat itu mengampuni pelanggarannya

Menurut Ibn Hajar (1999), hadis tersebut dikaitkan tentang kes perbuatan zina. Oleh yang demikian, sebahagian ulama mensyarahkan bahawa hadis tersebut berkaitan dengan seorang lelaki yang datang menemui Rasulullah s.a.w. dan mendakwa dirinya telah melakukan suatu perbuatan yang dianggapnya berzina, sedangkan ia masih belum boleh dimutlakkan sebagai berzina. Ini kerana, hadis tersebut seterusnya menceritakan bahawa perbuatan solat yang telah dilakukan lelaki berkenaan telah menghapuskan dosanya. Ibn Hajar melanjutkan perbincangan dengan menisbahkan kisah hadis tersebut kepada kisah Nabhan al-Tammar iaitu seorang lelaki yang telah mencium seorang perempuan bukan muhrimnya. Menurut pandangan Ibn Hajar, kemungkinan lelaki tersebut berpandangan bahawa setiap kesalahan memiliki 
hukuman hadd tertentu, maka dia mengatakan bahawa dirinya telah melakukan satu kejahatan yang berhak mendapat hukuman hadd. Justeru, hadis ini telah dijadikan dalil tentang tidak perlu dijatuhkan hukuman hadd terhadap seorang yang melakukan perbuatan mencium atau menyentuh perempuan yang haram baginya (tanpa berlakunya zina). Pendapat ini telah memetik pandangan Ibn al-Mundhir yang menyatakan, tidak diwajibkan hukuman hadd meskipun kedua pasangan tersebut berada dalam satu pakaian, selagi tidak berlakunya zina. Pandangan ini turut disokong oleh al-Qurtubi (2000) di dalam kitab tafsirnya.

Setelah meneliti hujah-hujah golongan mufasirin dan muhaddithin dalam membahaskan tentang ayat inna al-hasanat yuzhibna al-sayyi'at serta hadis-hadis yang menjadi asbab al-nuzul kepada ayat tersebut, satu penilaian dapat disimpulkan. Persoalan pertama, adakah dengan menunaikan solat sahaja segala perbuatan kejahatan akan dihapuskan? Dalam erti kata lain, apakah maksud sebenar perkataan al-hasanat? Adakah ia khusus kepada amalan solat sahaja atau sebaliknya? Persoalan seterusnya, adakah amalan kebaikan tersebut boleh menghapuskan segala dosa manusia? Berdasarkan kepada tafsiran perkataan al-hasanat yang telah dihujahkan oleh para ulama tersebut, didapati kebanyakan mereka mentafsirkan nas tersebut secara umum iaitu meliputi segala amalan kebaikan termasuklah solat, sedekah, istighfar dan sebagainya. Hanya segelintir ulama sahaja yang menolak pandangan ini iaitu al-Tabari dan Mujahid. Justeru, kajian ini mengambil pandangan jumhur iaitu amalan kebaikan tersebut adalah meliputi semua amalan kebaikan (termasuklah kebajikan) yang diterima oleh syarak. Tujuannya adalah bagi menjawab persoalan pertama iaitu adakah dengan solat sahaja boleh menebus kesalahan yang telah dilakukan. Selanjutnya, bagi menjawab persoalan kedua iaitu adakah amalan kebaikan tersebut boleh menghapuskan segala dosa manusia? Atau dengan kata lain, sejauh mana ukuran kejahatan yang dimaksudkan? Adakah ia meliputi dosa besar dan dosa kecil? Justeru, kajian ini mengambil pandangan al-Shawkani, dan bersetuju bahawa perkataan al-sayyi'at dalam petikan ayat tersebut telah dinaskan secara khusus yang membawa maksud dosa-dosa kecil sahaja. Pandangan ini mengambil kira, andainya amalan kebaikan tersebut boleh melupuskan segala dosa, mengapa pula agama Islam masih menganjurkan konsep taubat nasuha bagi mereka yang telah melakukan dosa-dosa besar kepada Allah s.w.t.?

Kesimpulan kajian, perintah khidmat masyarakat boleh diletakkan sebagai satu bentuk amalan kebaikan yang boleh melupuskan dosa-dosa kecil, iaitu dinisbahkan kepada kesalahankesalahan kecil. Ia berdasarkan kepada dalil-dalil hadis yang lalu, perbuatan mencium seorang perempuan yang haram baginya telah diletakkan sebagai satu bentuk kesalahan takzir dan ia boleh dinisbahkan kepada kesalahan-kesalahan kecil dalam Islam. Manakala, hukuman yang dikenakan ke atasnya adalah solat yang boleh dinisbahkan kepada amalan-amalan kebaikan ataupun kebajikan. Ini jelas membuktikan bahawa segala kesalahan kecil yang dikategorikan dalam kesalahan takzir boleh dilupuskan dengan melakukan amalan-amalan kebaikan seperti perintah khidmat masyarakat atau sebagainya. Namun begitu, pelaksanaan khidmat masyarakat yang dilakukan oleh pesalah terbabit haruslah didasari dengan hati yang tulus dan ikhlas. Di sinilah yang membezakan bentuk hukuman antara Islam dan Barat. Sesungguhnya, agama Islam adalah agama yang suci, dan segala bentuk hukuman yang terdapat dalam Islam menghendaki pesalah kembali kepada fitrahnya dengan hati yang ikhlas bukan atas dasar paksaan. Secara ringkas, kajian ini telah membicarakan tentang pelaksanaan perintah khidmat masyarakat dalam kerangka perundangan fiqah dengan membuat perbandingan di antara pandangan sivil dan Islam terhadap beberapa aspek perbahasan. Amnya, terdapat banyak persamaan di antara konsep perintah khidmat masyarakat yang dibahaskan oleh sarjana Barat dengan konsep hukuman takzir dalam perundangan Islam. Pertama, perintah khidmat masyarakat dilihat sebagai salah satu bentuk hukuman alternatif kepada pemenjaraan atau lain-lain hukuman, sama seperti hukuman takzir yang dilihat sebagai alternatif kepada hukuman hudud dan qisas yang tidak dapat dilaksanakan atas sebab-sebab tertentu. Kedua, dalam aspek kuasa budi bicara hakim, kedua-dua bentuk hukuman ini sama ada perintah khidmat masyarakat mahupun takzir, merupakan hukuman yang didasarkan kepada kuasa budi bicara hakim. Namun, ia masih 
tertakluk kepada sistem pemerintahan negara tertentu, atau dari sudut perundangan Islam, ia perlu dilihat dalam konteks siyasah syariyyah. Ketiga, dari aspek teori atau matlamat asas penghukuman, didapati wujudnya persamaan di antara teori asas perintah khidmat masyarakat dengan falsafah perundangan undang-undang jenayah Islam. Ini dapat dilihat melalui teori pemulihan (rehabilitative) dan pembaikpulihan (restorative) dalam konteks perintah khidmat masyarakat, menyerupai falsafah pendidikan ( $\left.t a^{\prime} d i b\right)$ dan pemulihan (islah) dalam konteks undang-undang jenayah Islam. Manakala teori seperti pencegahan (deterrence) dan pemulihan semula (reparative) dalam perintah khidmat masyarakat juga terdapat dalam falsafah perundangan hukuman takzir. Selanjutnya, dalam aspek penebusan dosa, perbahasan oleh sarjana Islam lebih terperinci dalam membincangkan elemen ini berbanding dengan sarjana Barat. Malah, sarjana Islam juga telah membahaskannya secara mendalam elemen ini dengan mengambil kira dari sudut sejarah mahupun sebab penurunan ayat berkaitan penebusan dosa, serta pandangannya yang berbeza-beza. Hal sedemikian membuktikan bahawa perintah khidmat masyarakat adalah satu bentuk hukuman yang turut terdapat dalam syarak, dan dilihat mempunyai prospek yang cerah bagi tujuan pelaksanaannya di Mahkamah Syariah Malaysia.

\section{References}

Al-Quran.

Al-Qur'an Mushaf Malaysia dan Terjemahan. 1994. Cetakan ke-4. Shah Alam: Yayasan Restu.

Abu Rakhyah, Majid. 2010. Al-Wajiz fi Ahkam al-Hudud wa al-Qisas wa al-Ta `zir. `Amman: Dar alNafa'is.

Abu Zahrah, Muhammad. 1974. Al-Jarimah wa al-'Uqubah fi al-Fiqh al-Islamiy. Cairo: Dar al-Fikr al-'Arabi.

'Audah, `Abdul Qadir. 1993. Al-Tasyri' al-Jina'i al-Islami. Juz. 1. Cairo: Maktabah Dar al-Turath.

Baer, B. F. 1991. When prison isn't punishment enough: The effective use of home incarceration, community service, curfew parole, and substance abuse testing. Criminal Justice 6: 3-8.

Brennan, B.Y.T.P. \& Mason, L. 1983. Community service: A developing concept. Federal Probation 47: 49-57.

al-Bukhari, Abu `Abd Allah Muhammad. 2012. Sahih al-Bukhari. Tahqiq. Markaz al-Buhuth wa Taqniyah al-Ma'lumat. Jil. 8. Cairo: Dar al-Ta'sil.

Carter, R.M., Cocks, J. \& Glaser, D. 1987. Community service: A review of the basic issues. Federal Probation 51(1): 4-10.

El-Ewa, Mohamed S. 1999. Hukuman dalam Undang-undang Islam: Satu Kajian Perbandingan. Transl. Kuala Lumpur: Dewan Bahasa dan Pustaka.

Flacks, M. 2006. Combining retribution and reconciliation: The role of community sentencing in transitional justice. Interdisciplinary Journal of Human Rights Law 1(1): 1-26.

Groves, P.H. 1977. A report on community service treatment and work programs in British Columbia. Canadian Journal Criminology \& Corrections 19: 119-150.

Hudson, J. \& Galaway, B. 1990. Community service: Toward program definition. Federal Probation 54(2): 3-9.

Ibn `Abidin, Muhammad Amin al-Syahid. 1966. Hashiyah Radd al-Mukhtar. Juz. 4. Cetakan ke-2. Mesir: Syarikah Maktabah wa Matba`ah Mustafa al-Babi al-Jalli wa Awladuh.

Ibn `Asyur, Muhammad Tahir. 1978. Maqasid al-Shari`ah al-Islamiyyah. Tunis: Al-Sharikah alTunisiyyah.

Ibn Farhun, Burhanuddin Abi Wafa' Ibrahim. 1995. Tabsirah al-Hukkam fi Usul al-Aqdiyah wa Manahij al-Ahkam. Juz. 1. Beirut: Dar al-Kutub al-'Ilmiyyah.

Ibn Hajar al-`Asqalani, Ahmad bin `Ali. 1999. Fathul Bari: Sharah Sahih al-Bukhari. Juz. 12. Cairo: Dar al-Mannar.

Ibn Kathir, Abu al-Fida' Ismail bin 'Imran. 1997. Tafsir al-Qur'an al-'Azim. Jil. 4. Cetakan ke-2. Riyadh: Dar Tayyibah. 
Ibn Qudamah, al-Maqdisi. 1996. Al-Mughni. Juz. 12. Cairo: Dar al-Hadith.

al-Kasany, `Alauddin Abi Bakr bin Mas`ud. 1996. Kitab Bada'i’ al-Sana'i’ fi Tartib al-Shara'î. Juz. 7. Beirut: Dar al-Fikr.

Leibrich, J., Galaway, B. \& Underhill, Y. 1986. Community service sentencing in New Zealand: A survey of users. Federal Probation 50(1): 55-64.

al-Mawardi, Abu Hassan `Ali bin Muhammad bin Habib al-Basri. 1985. Al-Ahkam al-Sultaniyyah wa al-Wilayat al-Diniyyah. Beirut: Dar al-Kutub al-'Ilmiyyah.

al-Nasa'i, Imam Abu `Abd al-Rahman Ahmad. 2012. Sunan al-Nasa'i. Tahqiq. Markaz al-Buhuth wa Taqniyah al-Ma'lumat. Juz. 7. Cairo: Dar al-Ta'sil.

al-Nawawi, Muhyiy al-Din Abu Zakariyya Yahya. 1999. Sahih Muslim bi Sharh al-Nawawi. Jil. 9. Cairo: Dar al-Fajr li Turath.

Panzer, C. 1997. Community service order. Crime and Justice: An Annual Review of Research 6: 51-94.

Perrier, D.C. \& Pink, F.S. 1985. Community service: All things to all people. Federal Probation 49(2): 32-38.

al-Qurtubi, Abu Abdullah Muhammad bin Ahmad al-Ansari. 2000. Al-Jami`li Ahkam al-Qur'an. Jil. 5. Beirut: Dar al-Kutub al-'Ilmiyyah.

Reddy, B. 1991. Community service order: An alternative sentence. Singapore Academy of Law Journal 3(2): 230-237.

Rubin, H.T. 1985-1986. Community service restitution by juveniles: Also in need of guidence. Juvenile \& Family Court Journela 77(1): 1-8.

Sayyid al-Qutb. 1987. Fi Zilal al-Qur'an. Jil. 4. Cetakan ke-13. Beirut: Dar al-Shuruq.

al-Shawkani, Muhammad `Ali bin Muhammad. 1995. Fath al-Qadir: Al-Jami` bayn Fanniy alRiwayah wa al-Dirayah min 'Ilm al-Tafsir. Juz. 2. Beirut: Maktabah al-`Asriyyah.

Siti Zubaidah Ismail. 2011. Hukuman alternatif dari perspektif undang-undang syariah. Shariah Law Report 4: 25-41.

Skeen, A. S. 1988. Community service order. South Africa Criminal Journal (SACJ) 2: 206-337.

al-Suyuti \& al-Sindi. 1999. Sunan al-Nasai bi Sharah al-Imamayn al-Suyuti wa al-Sindi. Juz. 4. Cairo: Dar al-Hadith.

al-Syirazi, Abu Ishaq Ibrahim bin `Ali bin Yusuf. 1995. Al-Muhadhab fi Fiqh al-Imam al-Syafi ì. Juz. 3. Beirut: Dar al-Kutub al-Ilmiyyah.

al-Tabari, Abu Ja`far Muhammad bin Jarir. 2005. Tafsir al-Tabari: Jami` al-Bayan 'an Ta’wil alQur'an. Jil. 6. Cairo: Dar al-Salam.

Umbreit, M. S. 1981. Community service sentencing: Jail alternative or added sanction? Federal Probation 45: 3-14.

Vass, A.A. \& Menzies, K. 1989. Community service order as a public and private enterprise: A comporative account of practice in England and Ontario, Canada. Britain Journal Criminal 29(3): 255-272.

Walgrave, L. \& Geudens, H. 1996. The restorative proportionality of community service for juveniles. European Journal of Crime, Criminal Law and Criminal Justice 4: 361-380. 